\title{
Are Haematological Parameters Reliable for Differential Diagnosis of Testicular Torsion and Epididymitis?
}

\author{
Hematolojik Parametreler Testiküler Torsiyon ve Epididimit Ayıııcı Tanısında Güvenilir Midir?
}

\author{
iD Reha Girgin, iD Önder Çınar, iD N. Aydın Mungan \\ Zonguldak Bülent Ecevit University Faculty of Medicine, Department of Urology, Zonguldak, Turkiye
}

What's known on the subject? and What does the study add?

Although, these tests were insufficient to differentiate testicular torsion and epididymo-orchitis, can narrow the indications for exploration for acute scrotum. However, exploration still remains important in suspected cases.

\begin{abstract}
Objective: Acute scrotum is a urological emergency that can result in loss of the testis if the differential diagnosis is not made immediately. Testicular torsion (TT) and epididymo-orchitis (EO) are the two most common causes of acute scrotum. Our aim was to evaluate the utility of haematological parameters for the diagnosis of both $\Pi$ and $E 0$ and for differential diagnosis of these two conditions.

Materials and Methods: Data of 98 patients who applied because of acute scrotum between January 2007 and April 2018 were retrospectively analyzed. The patients were divided into three groups: those with $\Pi$ diagnosis, with EO diagnosis and controls with the diagnosis of other noninflammatory conditions. Demographic data, complete blood count and biochemical parameters at admission were recorded. Values for these parameters along with platelet-to-lymphocyte ratio (PLR), neutrophil-to-lymphocyte ratio (NLR) and platelet mass index (PMI) were examined for all groups. The specificity, sensitivity and positive and negative predictive value of parameters that were statistically significant were compared between the groups.

Results: Of the 98 patients included in this study, 32 were in the first group, 41 were in the second and 25 were in the third group. The mean neutrophil count in the $\Pi, E 0$ and control groups was $8.7,7.2$ and 5.4 , respectively $(p=0.001)$. The mean leukocyte count was $11.8,10.8$ and 8.3 in the $\Pi, E O$ and control groups, respectively $(p=0.003)$. There was no statistically significant difference in mean lymphocyte count, mean platelet count and PLR, NLR, and PMI between the groups.
\end{abstract}

Conclusion: Although, these tests were insufficient to differentiate $\Pi$ from EO, we think that they may narrow the indications for emergent exploration for acute scrotum.

Keywords: Testicular torsion, Inflammation, Differential diagnosis

\section{Ozz}

Amaç: Akut skrotum, ayırıcı tanı hemen yapılmazsa testis kaybına neden olabilecek ürolojik bir acil durumdur. Testiküler torsiyon (TT) ve epididimoorşit (EO) akut skrotumun en yaygın iki nedenidir. Hematolojik parametrelerin hem $\Pi$ hem de EO tanısı ve bu iki hastalığın ayırıcı tanısı için yararlılığını değerlendirmekti.

Gereç ve Yöntem: Akut skrotum nedeniyle Ocak 2007-Nisan 2018 tarihleri arasında başvuran 98 hastanın verileri retrospektif olarak incelendi. Hastalar üç gruba ayrıldı. İlk grup $\Pi$ tanısı, ikinci grup EO tanısı olan ve üçüncü grup enflamatuvar olmayan nedenlerden oluşan kontrol grubu. Tüm grupların giriş sırasındaki demografik veriler, tam kan sayımı ve biyokimyasal parametreler kaydedildi. Bu parametreler içinde platelet / lenfosit oranı (PLR), nötrofil / lenfosit oranı (NLR) ve trombosit kitle indeksi (PMI) değerlendirildi. Özgüllük, duyarlılık, pozitif ve negatif prediktif değerler, istatistiksel olarak anlamlı olan parametreler için gruplar arasında karşılaştırıldı.

Bulgular: Çalışmaya alınan doksan sekiz hastanın 32'si birinci, 41'i ikinci, 25'i üçüncü gruptaydı. Ortalama nötrofil değerleri $\Pi$ grubunda 8,7, E0 grubunda 7,2 ve kontrol grubunda 5,4 idi ( $p=0,001)$. Ortalama lökosit değerleri T grubunda 11,8, E0 grubunda 10,8 ve kontrol grubunda 8,3 idi $(p=0,003)$. Gruplar arasında ortalama lenfosit sayısı, ortalama trombosit sayısı ve PLR, NLR, PMI açısından istatistiksel fark yoktu.

Correspondence: Reha Girgin, Zonguldak Bülent Ecevit University Faculty of Medicine, Department of Urology, Zonguldak, Türkiye Phone: +90 5378865912 E-mail: mujdereha@hotmail.com ORCID-ID: orcid.org/0000-0003-1132-8629

Received: 24.05 .2019

Accepted: 01.12.2019

Cite this article as: Girgin R, Çınar Ö, Mungan NA. Are Haematological Parameters Reliable For Differential Diagnosis of Testicular Torsion and Epididymitis? J Urol Surg 2020;7(2):109-113.

๑Copyright 2020 by the Association of Urological Surgery / Journal of Urological Surgery published by Galenos Publishing House. 
Sonuç: Her ne kadar bu testler T ve EO'yu ayırt etmek için yetersiz olsa da, akut skrotum için acil eksplorasyon endikasyonlarını daraltabileceğini düşünmekteyiz.

Anahtar Kelimeler: Festis torsiyonu, Enflamasyon, Ayırıcı tanı

\section{Introduction}

Inflammation of the scrotum or its components with local and systemic signs and symptoms is defined as acute scrotum (1). Testicular torsion (T), epididymo-orchitis (EO), tumor, hydrocele and varicocele. should be considered in the differential diagnosis. Although the most common cause of acute scrotum is EO, the diagnosis of $\Pi$ should have an urgent priority (2). Even with a good physical examination and history, laboratory and imaging methods need to be used to support the diagnosis in one-third of patients (2).

Power Doppler ultrasonography (USG) is the most commonly used imaging method in the differential diagnosis for being simple, non-invasive and very sensitive (3). It is not always possible to use emergency imaging methods in rural areas and unavailability of these methods may lead to unnecessary interventions or delay in diagnosis. Therefore, reducing the dependence on imaging methods and finding new diagnostic methods will help the clinician to make decision under these difficult conditions.

There are many reports on the use of inflammatory markers for the differential diagnosis of $\Pi$ (3). In this study, we tried to investigate whether we could benefit from the hematological parameters mentioned in the literature for differentiating $\Pi$ from EO.

\section{Materials and Methods}

After confirmation of the presence of patients' written consent, data of 709 patients, who applied to our urology and emergency departments due to acute scrotum between January 2007 and April 2018, were analyzed retrospectively. Ninety-eight patients with complete data were included in this study. The patients were divided into three groups: those with $\Pi$ diagnosis, with EO diagnosis and controls with a diagnosis of other noninflammatory conditions. In the $\Pi$ group, patients with an interval of less than 12 hours between the onset of pain and $\pi$ were included in the study. Patients in the EO group, who had less than 12 hours between the onset of pain and admission to the hospital, were included in the study. The control group consisted of a group of patients with other causes that could ultimately lead to scrotal pain such as hydrocele, hernia, varicocele, appendix and $\Pi$. Patients with liver or renal dysfunction, haematological diseases and any malignancy were excluded from the study. All patients were evaluated by a specialist. Diagnosis was supported by physical examination, power Doppler USG of the scrotum and blood tests. Demographic data, complete blood count and biochemical parameters at admission were recorded for all groups. Values for these parameters along with platelet-tolymphocyte ratio (PLR), neutrophil-to-lymphocyte ratio (NLR) and platelet mass index (PMI) were examined in all groups. The specificity, sensitivity, positive and negative predictive value of parameters that were statistically significant were compared between the groups. This study obtained local ethics committee approval (Protocol number:2018-193-26/09).

\section{Statistical Analysis}

Statistical analyses were performed with the SPSS 19.0 software (SPSS Inc., Chicago, IL, USA). Distribution of data was determined by the Shapiro-Wilk test. Continuous variables were expressed as mean \pm standard deviation or median (minimum-maximum). Differences among the groups were analyzed by the KruskalWallis test or ANOVA for continuous variables. Dual comparisons among groups with significant values were evaluated with the Dunn's test after the Kruskal-Wallis test. A receiver operating characteristic (ROC) analysis was conducted to determine the best cut-off value to predict the outcome. A $p$ value of less than 0.05 was considered statistically significant.

\section{Results}

Of the 98 patients included in this study, 32 were in the first group, 41 were in the second and 25 were in the third group. The clinical and demographic data of the groups are shown in Table 1.

There was a statistically difference between the groups in terms of mean neutrophil and leukocyte count (Figure 1,2). Although there was no difference between the $\Pi$ and the EO groups, the values in the control group were lower. There was no significant difference in mean lymphocyte count, platelet count, mean platelet volume (MPV), NLR PLR and PMI values between the groups.

ROC analysis used to estimate EO and $\Pi$ found the best cutoff value for neutrophil and leukocyte count for the first group provided a sensitivity of $84.4 \%$ and $90.6 \%$, respectively and a specificity of $76 \%$ and $68 \%$, respectively. The same parameters in the second group had a sensitivity of $56.1 \%$ and $68.3 \%$, respectively and a specificity of $84 \%$ and $68 \%$, respectively. Data related to the ROC analyses are shown in Figure 3 and 4. 


\begin{tabular}{|c|c|c|c|c|}
\hline & $\begin{array}{l}\text { Control } \\
n=25\end{array}$ & $\begin{array}{l}\text { Torsion } \\
\mathrm{n}=32\end{array}$ & $\begin{array}{l}\text { Epididymitis } \\
\mathrm{n}=41\end{array}$ & $\mathbf{p}$ \\
\hline Age (years) & $34(13-72)$ & $16(10-41)$ & $43(10-84)$ & 0.001 \\
\hline Neutrophil $\left(\mathrm{x} 10^{3} \mu \mathrm{L}\right)$ & $5.4(3.6-14)$ & $8.7(3-14.3)$ & $7.2(1.6-27.5)$ & 0.001 \\
\hline Leucocytes $\left(x 10^{3} \mu \mathrm{L}\right)$ & $8.3(5.7-17.7)$ & $11.8(7.2-16.8)$ & $10.8(4.6-33.9)$ & 0.003 \\
\hline Lymphocytes $\left(\times 10^{3} \mu \mathrm{L}\right)$ & $2(0.5-6.3)$ & $1.95(0.8-5)$ & $1.9(0.5-7.2)$ & 0.864 \\
\hline Platelet $\left(\times 10^{3} \mu \mathrm{L}\right)$ & 239 (174-418) & $269.5(130-364)$ & $263(150-792)$ & 0.283 \\
\hline Mean platelet volume (fL) & $8.3(6.8-10.1)$ & $8(6.6-10.1)$ & $8.2(6.5-11.2)$ & 0.486 \\
\hline Neutrophil/lymphocyte & $2.56(0.59-56)$ & $4,58(0.68-13)$ & $4.43(0.4-23.3)$ & 0.063 \\
\hline Platelet/lymphocyte & $119.5(40.63-416)$ & $111.62(42.5-323)$ & $133.33(54.03-656)$ & 0.340 \\
\hline PMI & $1888.1(1548.6-3218.6)$ & $2176(259.2-2870.4)$ & $2162(1479.8-6336)$ & 0.191 \\
\hline
\end{tabular}

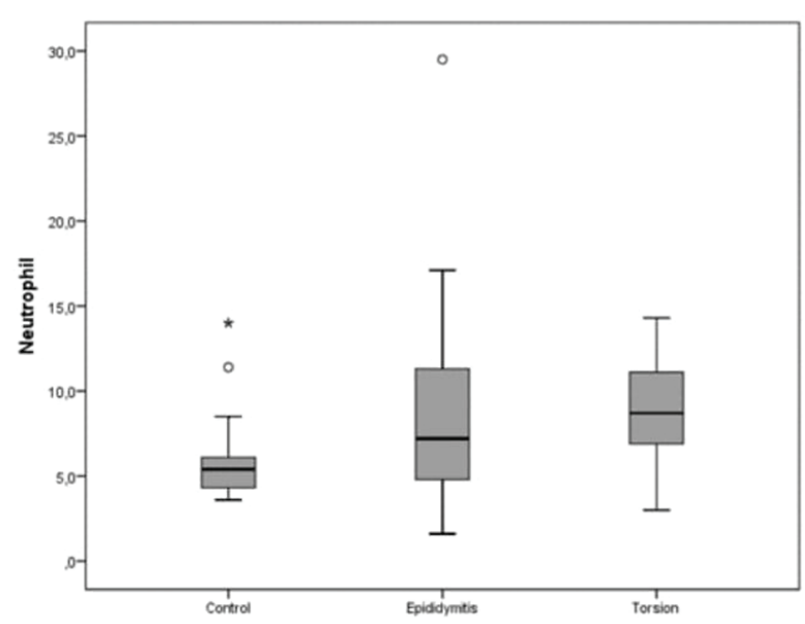

Figure 1. Box graph of neutrophil according to groups

\section{Leucocyte}

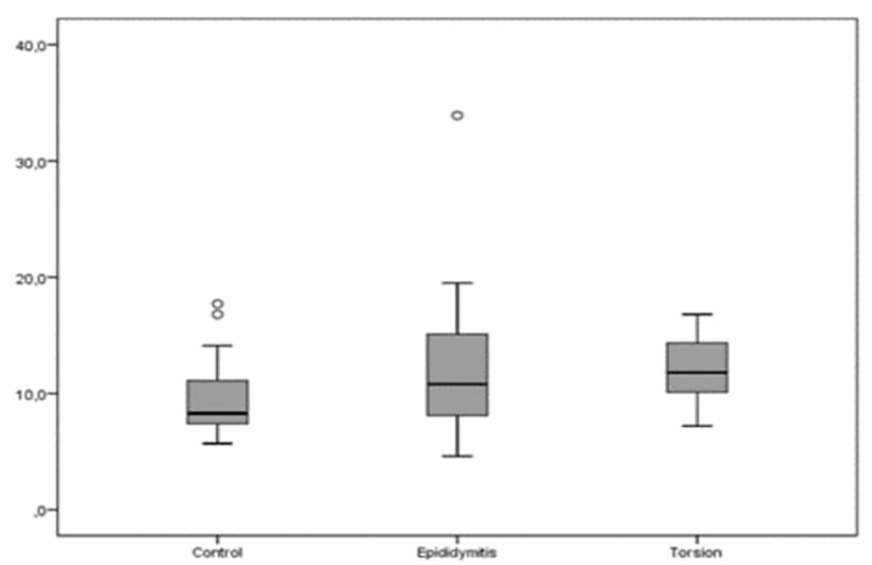

Figure 2. Box graph of Leucocyte according to groups

\section{Discussions}

Acute scrotum is a urological emergency that can result in loss of the testis if the differential diagnosis is not made immediately. $\Pi$ and EO are the two most

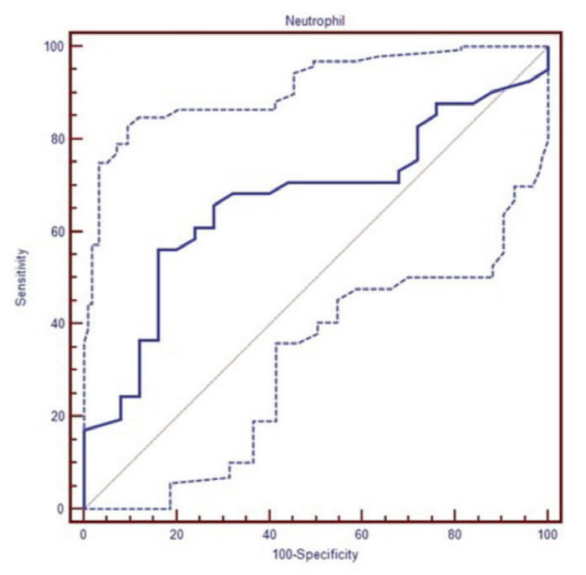

leukocyte

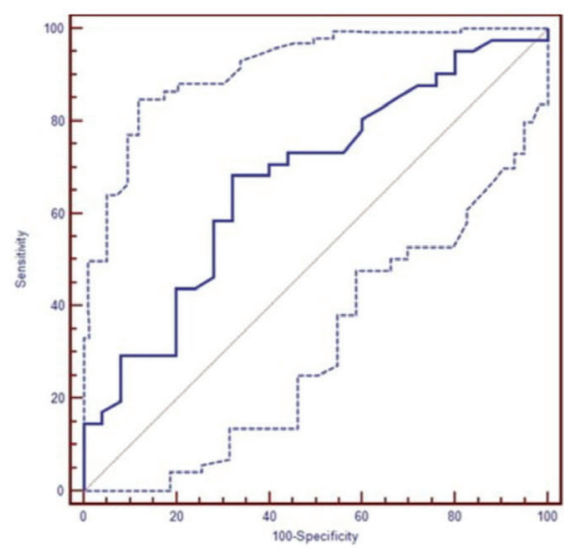

Figure 3. Receiver operating characteristic graph of leukocyte and neutrophil in the epididymitis group

common causes of acute scrotum. Both conditions are known to produce an inflammatory response.

Several hematological parameters have been studied to be used in the differential diagnosis of both diseases. Infection, tissue ischemia, cancer, trauma, and surgical procedures create an acute 

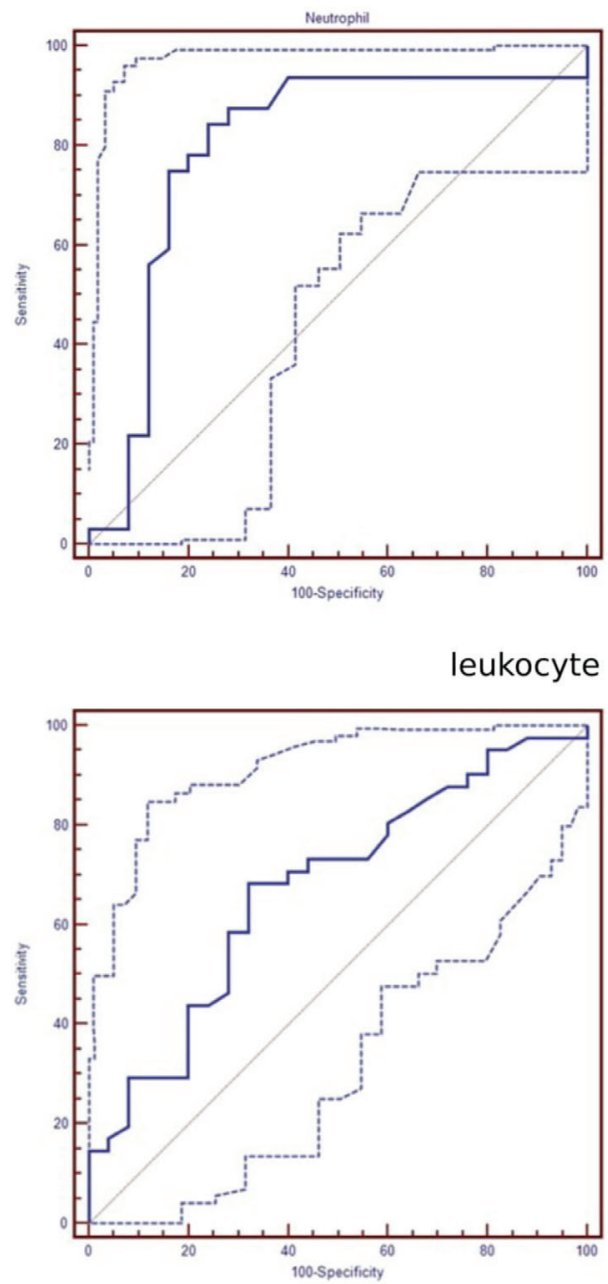

Figure 4. Receiver operating characteristic graph of leukocyte and neutrophil in the toursion group

phase protein response with the acute stress that they create in the organism. For this purpose, erythrocyte sedimentation rate and C-reactive protein (CRP), were studied by Asgari et al. (2) and both were found to be higher in the epididymitis group. In another study, only the high level of CRP was shown to be significant (4). Another study evaluating the value of another acute phase reactant, procalcitonin, in the differential diagnosis of $\Pi$ also found an elevation in the epididymitis group of rats (5).

In a biological system, systemic inflammation can be demonstrated by several markers, including leukocyte, neutrophil and lymphocyte counts (6). A significant increase in leukocyte count in patients with $\Pi$ has been shown in different studies $(7,8)$. Similar to that in a study by Bitkin et al. $(9)$, the mean leukocyte count was significantly higher in the $\Pi$ and EO groups than in controls in our study. However, there was no significant difference between the $\Pi$ and EO groups. According to our findings, leukocyte count does not appear to be helpful in the differentiating $\Pi$ from EO.
Thrombocytes are involved in the inflammatory processes through their interactions with immune and non-immune cells via a variety of cytokines (10). Platelet count is determined by the balance between production and destruction processes in the circulation. As the size of the thrombocytes increase in the circulation, they are considered to be more active. The size of the platelets is expressed simply by MPV (11). However, it has been reported that platelet count can serve as indicators of platelet activity as well as platelet volume, leading to the identification of PMI as an indicator that takes into account both parameters (6). In some studies, the differential diagnosis of acute scrotum was made by using platelet count and MPV (7). PMI has not been studied for this purpose before. In one study, the MPV value was significantly increased in the $\Pi$ group, but not in another study $(7,12)$. Whereas, in the study of Bitkin et al. (9), the MPV value was found to be equal in both the $\Pi$ group and the EO group but higher than in controls. In one study, platelet counts were higher in $\Pi$ group (12). In another study, platelet counts were found to be equal in both $\Pi$ and control groups but higher in epidemiitis group (9). In our study, MPV and platelet count were found to be equal in $\Pi, E O$ and control groups. We also found no statistically significant difference in PMI between the groups.

Nowadays, hematological parameters, such as NLR, PLR and MPV are being used in the diagnosis of inflammation $(13,14)$. In many studies, these markers have been reported to have diagnostic and prognostic significance, especially in urological cancers $(15,16,17)$. Recently, these parameters have been studied in acute scrotum. In a study by Güneş et al. (12), PLR and NLR were found to be significantly higher in $\Pi$ patients than in controls. In a similar study by Bitkin et al. (9), the PLR value was higher in EO patients than in $\Pi$ patients and controls. When the NLR value was examined, it was similar in both the EO and $T$ groups but higher than in the control group. In our study, NLR, PLR, MPV and platelet count were found to be similar between the $\Pi, E O$ and control groups.

\section{Conclusions}

Diagnostic tools and haematological parameters can be insufficient within the clinician's limited time frame of decisionmaking; neutrophil count and leukocyte count can give rapid and useful information. Our findings revealed that however, these tests were insufficient to differentiate $\Pi$ from EO, but can differentiate $\Pi$ and $E 0$ from other causes of acute scrotum. We suggest that the use of haematological parameters in patients presenting with acute scrotum narrows the indications for exploration but does not eliminate it. The patient distribution between the groups was not homogeneous. Because of the fact that we were dependent on the patient data obtained from 
the hospital records and the number of patients with complete data divided into groups were not homogenous weakened the reliability of the study. There was a significant difference in the mean age between the groups included in the study during the study period. Age which is a factor that may affect hematological parameters was another weakness in our study. Therefore, our data that conflict with the literature should be supported by more comprehensive and well planned studies.

\section{Ethics}

Ethics Committee Approval: Institutional Board Approval was obtained from Clinical Research and Ethics Committee of Zonguldak Bülent Ecevit University (protocol number: 2018193-26/09).

Informed Consent: Written consent was obtained from all patients.

Peer-review: Internally peer-reviewed.

\section{Authorship Contributions}

Concept: R.G., Design: R.G., Data Collection or Processing: R.G., Ö.Ç., Analysis or Interpretation: R.G., Ö.Ç. Literature Search: R.G., Ö.Ç., Writing: R.G.

Conflict of Interest: No conflict of interest was declared by the authors.

Financial Disclosure: The authors declare that they have no relevant financial.

\section{References}

1. Doehn C, Fornara P, Kausch I, Büttner H, Friedrich HJ, Jocham D. Value of acute-phase proteins in the differential diagnosis of acute scrotum. Eur Urol 2001;39:215-221.

2. Asgari SA, Mokhtari G, Falahatkar S, Mansour-Ghanaei M, Roshani A, Zare A, Zamani M, Khosropanah I, Salehi M. Diagnostic accuracy of C-reactive protein and erythrocyte sedimentation rate in patients with acute scrotum. Urol J 2006;3:104-108.

3. Bitkin A, Aydın M, Özgür BC, Irkilata L, Akgunes E, Keles M, Sarıcı H, Atilla MK. Can haematologic parameters be used for differential diagnosis of testicular torsion and epididymitis? Andrologia 2018;50. doi: 10.1111/ and.12819.

4. Meštrović J, Biočić $\mathrm{M}$, Pogorelić $\mathrm{Z}$, Furlan $\mathrm{D}$, Družijanić $\mathrm{N}$, Todorić $\mathrm{D}$, Capkun $V$. Differentiation of inflammatory from non-inflammatory causes of acute scrotum using relatively simple laboratory tests: prospective study. J Pediatr Urol 2013;9:313-317.

5. Yamis $S$, Gedik A, Sahin H, Batun S, Nergiz Y, Bircan K. Is procalcitonin valuable in the differential diagnosis of testicular torsion and epididymoorchitis. Saudi Med J 2010;31:170-174.

6. Girgin R, Cinar O, Bulut E, Akduman B, Mungan NA. The Role of the Platelet Mass Index (PMI) as a New Prognostic Factor in Fournier's Gangrene. African J Urol 2018;24:226-232.

7. Cicek T, Togan $T$, Akbaba $K$, Narcı $H$, Aygun $C$. The value of serum mean platelet volume in testicular torsion. J Int Med Res. 2015;43:452-459.

8. Yang C Jr, Song B, Liu X, Wei GH, Lin T, He DW. Acute scrotum in children: an 18-year retrospective study. Pediatr Emerg Care. 2011;27:270-274.

9. Bitkin A, Aydın M, Özgür BC, Irkilata L, Akgunes E, Keles M, Sarıcı H, Atilla MK. Can haematologic parameters be used for differential diagnosis of testicular torsion and epididymitis? Andrologia 2018;50. doi: 10.1111/ and.12819.

10. Arbesu I, Bucsaiova M, Fischer MB, Mannhalter C. Platelet-borne complement proteins and their role in platelet-bacteria interactions. J. Thromb Haemost 2016;14:2241-2252.

11. Gasparyan AY, Ayvazyan L, Mikhailidis DP, Kitas GD. Mean platelet volume: a link between thrombosis and inflammation? Curr Pharm Des 2011;17:4758.

12. Güneş $M$, Umul $M$, Altok $M, A$ kyuz $M$, Işsoğlu $C S$, Uruc $F$, Aras $B, A$ kbaş $A$, Baş E. Predictive role of hematologic parameters in testicular torsion. Korean J Urol 2015;56:324-329.

13. Azab B, Zaher M, Weiserbs KF, Torbey E, Lacossiere K, Gaddam S, Gobunsuy $R$, Jadonath $S$, Baldari $D$, McCord $D$, Lafferty J. Usefulness of neutrophil to lymphocyte ratio in predicting short- and long-term mortality after nonST- elevation myocardial infarction. Am J Cardiol 2010;106:470-476.

14. Slavka G, Perkmann T, Haslacher H, Greisenegger S, Marsik C, Wagner OF, Endler $\mathrm{G}$. Mean platelet volume may represent a predictive parameter for overall vascular mortality and ischemic heart disease. Arterioscler Thromb Vasc Biol 2011;31:1215-1218.

15. Günay E, Sarınç Ulaşlı S, Akar O, Ahsen A, Günay S, Koyuncu T, Unlü M. Neutrophil-to- lymphocyte ratio in chronic obstructive pulmonary disease: a retrospective study. Inflammation 2014;37:374-380.

16. Karabacak M, Dogan A, Turkdogan AK, Kapci M, Duman A, Akpinar O. Mean platelet volume is increased in patients with hypertensive crises. Platelets 2014;25:423-426.

17. Wei $Y$, Jiang YZ, Qian WH. Prognostic role of NLR in urinary cancers: A metaanalysis. PLoS One 2014;9:e92079. 